This is a self-archived version of an original article. This version may differ from the original in pagination and typographic details.

Author(s): Hasu, Päivi

Title: Faith-based development of World Vision Tanzania

Year: 2018

Version: Accepted version (Final draft)

Copyright: (c) 2018 Taylor \& Francis

Rights: In Copyright

Rights url: http://rightsstatements.org/page/lnC/1.0/?language=en

Please cite the original version:

Hasu, P. (2018). Faith-based development of World Vision Tanzania. Journal of Contemporary

Religion, 33(3), 389-406. https://doi.org/10.1080/13537903.2018.1535361 


\section{Faith-based development of World Vision Tanzania}

Päivi Hasu

\section{ABSTRACT}

This article examines how faith is intertwined in conceptions of development in the work of World Vision Tanzania, a faith-based organisation focusing on child welfare. Issues that are explored include the question how an apparently common faith setting constitutes and provides a source of social meanings and values for the assessment of human development as well as secular development concepts as human agency and empowerment. The analysis shows how World Vision staff assign different values to Christian and nonChristian development when assessing the potential and achievements of the beneficiaries in terms of secular concepts. It is argued that a faith-based worldview in this context provides the foundation for the specific set of values and social meanings, which are examined in this article, and provides a source for these more generally when value judgments and assessments of agency, empowerment, freedom and, ultimately, well-being are made. It is further suggested that, by employing ideas of freedom, agency, and empowerment and investing them with Christian meaning, World Vision is able to generate a portrait of itself and its beneficiaries that is positioned in a hierarchy of values where Christian ideals and secular development fuse and become paramount. 


\section{KEYWORDS}

religion; development; Tanzania; World Vision

CONTACT paivi.m.hasu@jyu.fi

\section{Introduction}

In the past, development research has paid little attention to the impact of religion on developmental practice, rather examining it as a purely secular matter. ${ }^{1}$ This approach was aligned with the idea of modernising societies where religion was expected to play a diminishing role in public life. However, several scholars have demonstrated that the concept of development is rooted in religious traditions, such as Christianity, with their charitable engagements with poverty and justice (Plant and Weiss 2015, 56-58; Deacon and Tomalin 2015, 69). Religious institutions continue to hold important public positions in numerous developing countries, while faithbased organisations providea large proportion of social and health services, particularly in Sub-Saharan A frica. Currently, the widely accepted understanding is that, in faith contexts, religion affects what people consider worthwhile and valuable and that religion is integral to social, political, and economic life as well as development (Deneulin and Rakodi 2011, 48), ${ }^{2}$ informing how development is constructed, instituted, and received 
(Bornstein 2005, 1). Yet, academic studies of the faith-based organisation World Vision (WV), for example, have sometimes disregarded religion and faith and either treated the organisation as a secular NGO (e.g. Jefferess 2002; Kelsall and Mercer 2003; also De Wet 2013) or examined religion at an organizational level (King 2011; Whaites 1999). On the other hand, Erica Bornstein's ground-breaking study of the theology of development (2005) focuses on ideas of holism and life-style evangel ism, but the connection between secular and faith-based development receives less attention. This article addresses this lacuna by analysing religious rhetoric at the grassroots level of WV-recipient relations in Tanzania, thereby providing insight into how secular development concepts are imbued with religious meaning and how development ideals are conveyed to beneficiaries.

WV is one of the largest faith-based organisations in the world. Its historical roots lie in evangelical Christianity which emphasises the importance of conversion, evangelistic and missionary efforts, and the truth of the Bible (Bebbington 1989, 2-17); its principal development goal is to improve well-being through child-focused transformational development. This is reflected in its major programming paradigm: a transformational development framework which is supported by thework of Bryant Myers, W al king W ith theP oor ([1999] 2011). According to Myers, the nature of poverty is relational and its cause spiritual. Transformational development is, therefore, a holistic, biblical approach to development with physical, mental, social, and spiritual dimensions and thegoal of changing people and 
relationships operates on the understanding that spiritual transformation brings about transformations in other areas of human life (Myers [1999] 2011, 21).

Concurrently, the human development and capability approach, elaborated by A martya Sen since thelate 1970s (Sen 1979) has become a major paradigm in secular devel opment scholarship and its core conceptsdesirable 'beings and doings' (functionings), along with agency, empowerment, and freedom—are widely accepted. This approach (most advanced in Sen 1999) considers human development in terms of human capabilities: the things individuals can and cannot do in their situations in life, that is, their real opportunities to attain desired functionings (Sen 1999, 3-4, 17-19, 75). Thus the Human Development Report of 1990, based on Sen's conceptual work, defines human development as "the process of widening people's choices and the level of their achieved well-being" (UNDP 1990, 10). In Sen's view, freedom is both the goal of and the means to achieve human development.

The two concepts which are central to widening people's choicesagency and freedom—connote empowerment in the form of the expansion of agency and opportunities (Ibrahim and Alkire 2007, 383). Jo Rowlands has outlined four dimensions which are relevant to understanding the processes involved: 1) power over (ability to resist manipulation); 2) power to (generating new possibilities); 3) power with (acting collectively); 4) power from within (enhancing self-respect) (Rowlands 1997, 13; Ibrahim and Alkire 
2007, 384). During my periods of fieldwork in Tanzania between 2011 and 2014 (see details below), the last three dimensions of power were, substantively, the more salient in the discourse of both WV and its recipients, but the first, the 'power over', also deserves attention as it is implicated in the hegemony of the value system promoted by WV development. Myers has recognized that Sen's secular perception of human freedom and agency resonates with Christian views; however, he also points out that the two approaches part ways with regard to the Christian understanding that freedom is not the unlimited freedom of the Western self (Myers [1999] 2011, $31)$.

Anthropological perspectives on well-being remind us that well-being does not occur in the abstract; rather, it is culturally constituted (Lambek 2008; Jimenez 2008; M athews and Izquierdo 2009; Robbins 2013; Calestani 2009, 2013; Fischer 2014). Consequently, analysing social meanings within the capability framework, Séverine Deneulin and Allister McGregor (2010, 501$503,514)$ argue that its potential is diminished by insufficient acknowledgement of the social construction of meaning, which enables people to make value judgements about their own and others' well-being. Finally, Francis Stewart $(2013,5)$ has suggested that social institutions, such as norms, often sanctioned by religion, and organisations, such as NGOs, operate collectively to shape individual preferences and behaviour. Social institutions are, therefore, potentially instrumental in creating and enhancing particular capabilities. The source and importance of individual agency, for 
example, was stressed by WV staff and casts light on the arguments raised here because, as Michael Lambek has argued, it is necessary to investigate how the 'reasons to value' are established in a culture and society. In his critical remarks concerning Sen's individualistic view, Lambek further noted that the crucial anthropological question is: on what basis will people 'have reason to value' the lives they can live? He observes that it is necessary to bring the collective, culture, and society back into the picture to answer this question (Lambek 2008, 121). What people understand as valuable depends on shared meanings agreed upon in social collectives (Deneulin and McGregor 2010, 512).

The Dumontian framework of thinking about hierarchy, ideology and values suggests that, every time we evaluate one thing above another, we assign unequal values and create hierarchies (Strenski 2008, 42). ${ }^{3}$ This insight has inspired my examination of WV's intertwinement of religious and secular development ideas in its evaluations, the resulting hierarchical distinction between indigenous and Christian worldviews, and understandings of development potential. The question this raised is whether reflection on the other through the secular lenses of agency, empowerment, and freedom establishes Christian development as the paramount value.

The first aspect of the question to be explored is how an apparently common faith setting constitutes a source of social meanings and values for the assessment of human development, agency, and empowerment. The second aspect follows from the first as I examine WV staff's assignment of 
different values to Christian and non-Christian development when they assess the potential and achievements of the beneficiaries in terms of these three concepts. I argue that a faith-based worldview delimits the specific set of values and social meanings examined and provides the foundation for assessments of agency, empowerment, freedom, and, ultimately, well-being. I also suggest that by employing the ideas of freedom, agency, and empowerment and investing them with Christian meaning, WV is able to generate a portrait of itself and its beneficiaries as positioned in a hierarchy of values where Christian ideals and secular development fuse and become paramount. It is the topic of another article to examine how the adult guardians of the child beneficiaries, who make the development decisions at home, assess their own life situations, and how, or whether, Christian faith strengthens their own and their children's agency.

\section{World Vision Tanzania and the research area}

In 2014, WV Tanzania conducted programmes in 13 of the 60 regions in the country, mostly in the Lake, N orthern, and Central regions. In 2013, there were 62 Area Development Programmes (ADPs), 6 government grants, and 53 Private N on-Sponsorship Projects. Although WV's work is child-focused, the priority areas are: livelihoods; health, nutrition, water, sanitation, and hygiene; education; spiritual development, protection, and justice for children. The study's empirical research consisted of fieldwork conducted in two ADPs in the Shinyanga and Simiyu Regions (Lake region). An ADP 
typically involves $10,000-100,000$ people and about 10-15 villages.

Development priorities for an ADP are formulated by ADP committees, usually composed of village chair persons, representatives of civil groups, representatives of people with disabilities, and invited religious leaders from local churches. Each ADP also has a Christian Commitment Committee consisting of religious leaders, which mediates between the ADP and the local communities, providing spiritual services and assistance in implementing local development activities. Both projects studied were in the Lake Zone until 2014 when the zonal level in the WV organisation was abolished.

The first field site was a Canadian-financed ADP, located in a semiurban centre outside a rapidly growing town, on a busy road leading towards the border areas of Rwanda and Burundi in the Shinyanga Region. A nimal husbandry and the cultivation of maize, rice, ground nuts, sweet potatoes, and cassava are the most important sources of income for the local population. Educational and health services are provided by 14 primary schools, 3 secondary schools, 1 vocational school in the area, and 6 health centres. A large gold mine operates just outside the town. The project area has changed from rural to semi-urban in recent years, partly due to the large-scale rice industry which extends to other parts of East A frica. The ADP operates in the area of three wards which, according to the 2012 census, are populated by almost 44,000 people, with an average household size of between 4.5 and 6.2 people. The Christian Commitment Committee of this ADP comprises 12 leaders of the Roman Catholic Church and various Protestant denominations, 
including Pentecostal churches. In 2011, about $5 \%$ of the Canadian funding was allocated to the Christian Commitment Committee.

The other, more rural US-funded ADP in this study is located about 40 kilometres from the town of Bariadi in the Simiyu Region. Instituted in 2004, it operates in an area of three wards and covers 25 villages with about 41,000 people (according to the 2012 census) and an average household size of 7.48.0 people. The projects in this ADP include food security, health, education, leadership, and sponsorship. People practise cattle-herding and cultivate cotton, maize, and sunflowers. The Christian Commitment Committee resembles that of the other ADP.

A s indicated, zonal offices in the WV organisation in Tanzania were abolished in 2014, placing the ADP clusters directly under the directorship of the national office. A cluster is typically formed of three to four ADPs and shares the office of one of the ADPs. Clusters are led by Cluster Team Leaders who usually have a university degree, as do the ADP Co-ordinators. Each ADP tends to have two Development Facilitators and about ten Development Assistants, who are locally recruited and who work most closely with the people in the surrounding communities.

Nine months of fieldwork in total was conducted between 2011 and early 2015 in a study of religion and development, focusing on several faithbased organisations. Two months were spent specifically with WV, involving participation in daily office routines and training events, visits to sponsored families, and interviews with 20 staff members: 11 with Development 
Assistants (DAs), 3 with Development Facilitators (DFs), 4 with ADP Coordinators (PC), 2 with Cluster Team Leaders. Of these staff, 14 were male and 6 female; 8 were Roman Catholics (RC), 5 Pentecostals (PC), 3 Lutherans (KKKT), 2 were from the A frican Inland Church (AIC), 1 was Anglican, and 1 was a Seventh-Day Adventist (SDA ). A few individuals served as key informants, selected on the basis of their knowledge and experience in providing information about their culture. The accounts of the key informants are supported by the other interviews. Generally, WV staff members are versed in the language and terminology of secular development, which is reflected in their speech patterns. Many have several years, some have well over a decade, of WV experience, which, together with an analytical attitude, is also evident in the interviews. The interviews were semi-structured, conducted in the office environment, and generally lasted between 30 and 90 minutes; some informants were interviewed several times. Most conversations and interviews took place in Swahili, apart from those with informants who preferred to use English. Translations from Swahili to English are the author's. The discourses examined in this article are not formalised in WV directives although they are implicit in documents concerning transformational development and WV's empowerment model. This study, however, is about the values, attitudes, and interactions at the grassroots level where official policies are interpreted and applied-and enter into evaluations about development.

Staff reflections must be situated within broader ideological and 
programming frames. In the 2014 Annual Report of WV Tanzania, the National Director's opening sentence announced that “A transformed mind transforms the world". This reflects the major programming paradigm of WV: the transformational development framework (Myers [1999] 2011). A ministry framework and integrated programming model were devel oped for holistic and integrated Christian child-focused, community-based work. The goal is the sustained well-being of children within families and communities, especially the most vulnerable, which encompasses "enjoying good health, being educated for life, loving God and their neighbours, and being cared for, protected, and participating" (World Vision 2013, 2). The paradigm shift from service delivery to the Tanzania Empowerment ADP M odel (World Vision Tanzania 2012, 12) was introduced in the LakeZone in 2013.

In her detailed study of WV in Zimbabwe, Bornstein (2005, 48-53) has argued that the two central notions in the work of WV are holistic development—combining spiritual and material transformation and progress-and lifestyle evangelism—living a Christian life in the manner of Christ, thereby providing an example for non-believers. She suggests that these notions generate a conception of two distinct categories of people: the evangelised and developed and the un-evangelised and undeveloped. Consequently, WV has a stringent faith-based recruitment system which ensures that its practitioners bring faith-based values to their work in the office and the field. In discussing his attitudes to his work, one staff member in a leadership position demonstrated both the idea of holism—-that word and 
deed are one —and the idea of lifestyle evangelism—that one lives life as a

Christian example of Jesus and love:

This is the foundation: the work I do is that of God. It is not mine or that of WV or the national director or support office. It is God's work. To know this gives me the moral fibre to do my work diligently and reliably (uaminifu) for God and his people. When I serve somebody, I know I serve God and it encourages (kunipa moyo) me to do more. But my faith also teaches me about love (upendo). I do my work with people with love and I like them. This helps me a lot. I like the people in the villages, and I like to serve them. I like to see them change. This is the passion I have in my heart. Also the people below me in the cluster; I like them and I like to see them change and see them serve people. [...] In my leadership, I want to follow the example of Jesus Christ. I like to serve people like Jesus served. (208/2012, AIC male) ${ }^{4}$

This evaluation suggests that Scripture, biblical events, and protagonists serve as templates for the lives of people here and now (Lloyd 1966, 175). In the example above, the interlocutor relates his work to that of God, thereby verbalising its moral justification: the work of World Vision is the work of God and is further validated by Christian love. Through the use of analogy the informant associates the work in the cluster with the activities of Jesus and his disciples. Anthropologists, among others, have discussed the performative nature of Pentecostal language (Coleman 2004, 430, 436) represented here-a phenomenon that might be extended to Evangelical language. Ruth Marshall, for instance, argues that the experiential proximity of the biblical narrative brings the Bible's principal protagonists into the everyday lives of Christians (Marshall 2009, 89). Naomi Haynes, on the other hand, has argued that, for Pentecostals, analogy works to position people in relation to a particular constellation of elements represented by the biblical narrative. This means 
that analogy can position people differently within such a narrative (Haynes 2016).

The Tanzanian census does not allow questions about religious affiliation and it is therefore difficult to give exact figures of the religious composition of the WV ADP in Shinyanga. Generally, several government authorities and religious leaders estimated during the fieldwork discussions that up to two-thirds of its population 'do not have a religion', such as Christianity or Islam in this area, people 'without religion' are commonly referred to as 'pagans' by Christian Tanzanians. The remote areas of Shinyanga are portrayed as un-evangelised and undeveloped, with poor literacy rates, witchcraft, and albino killings. On the whole, during fieldwork, there was very little direct mention of the conversion or salvation of beneficiaries, although the WV Christian Commitment Committees composed of religious leaders do spread gospel-as-word in the World Vision project area. Rather more emphasis was placed on 'gospel as life', that is, lifestyle evangelism and 'gospel as deed' (Myers [1999] 2011, 21).

Drawing from the understanding that collective, shared meanings are the source and basis of perceptions and value judgements, this study proposes the faith-based worldview as such a source. Two processes appear to be relevant in this examination. I first discuss how Scripture might function as the general model for the particular in this world through the use of analogy, which A mos Yong calls a 'this is that' or 'then is now' hermeneutic (Yong 2010, 89). I then analyse whether, in the process of evaluating the 
development potential of non-Christian beneficiaries, WV staff hierarchise various religious practices, while also thinking through the use of secular development concepts.

\section{Biblical analogies to agents of development}

As the majority of local people 'do not have a religion', many of the issues staff members raised in the interviews about faith and development were framed by comparisons between Christianity and indigenous religion (imani ya asili) or 'pagan' beliefs (imani ya kipagani). Furthermore, while many WV operatives are conversant with secular development discourses and such concepts as capacity building, empowerment, implementation, and mobilisation (kuhamasisha), they easily switch between secular/ modernist ideas of development and biblical ideas of transformation. This section examines their characterisations of the notion of the good life before moving into the use of biblical analogies in staging the development scene.

WV staff considered serious poverty (maisha duni) and the lack of basic capabilities-food, clothing, housing, health care, and education-a hindrance to development (174/2012, 209/2012, DA, PC and 220/2012, Team Leader). The term duni translates into English as something like 'worthless' and 'insignificant'; a person in these circumstances may be described as being desperate (kukata tamaa) and suffering (anahangaika). Describing how this kind of grave poverty has increased, many also noted that it effectively hinders transition to the threshold level of basic 
capabilities and well-being. Serious poverty can also lead to complete despair, resulting in “many people becoming hopeless (kukata tamaa) with the realities of life here" (209/2012, DA). In contrast to serious poverty, the good life is described in Swahili as maisha bora while uzima perhaps best captures the idea of overall material and spiritual well-being-concerns also discussed by African theologians and other scholars (Magesa 1998; Olsson 2016) and described by several WV operatives in a similar way (e.g. 175/ 2012, DA; 206/ 2012, DA):

$M$ aisha bora is when a person has a house to live, food enough for the year, means of transportation such as a bike or car. Children are able to go to school, communication means such as radio and phone are there. Access to health care. Means to generate wealth. (205/ 2012, DA)

For many WV staff members, faith is an essential aspect of the good life (e.g. 174/ 2012, 206/ 2012, DA ). As one of them phrased it, “Wedepend on God in everything; we cannot manage on our own. Here people do not have the faith yet." (175/ 2012, DA) In other words, certainty and security do not originate in human agency but in living according to God's plans. The connections between spiritual and material poverty were the subject of considerable reflection among WV staff and resonate with official WV approaches to poverty as multi-dimensional, relational, and as having a fundamentally spiritual cause: the poor live in relationships that do not work for their wellbeing and may be positively disempowering (Myers [1999] 2011, 15). In what follows, I examine the use of biblical analogies by WV staff when they reflected on agency, empowerment, and the possibility of freedom and on the 
way they evaluated beneficiaries' development potential.

Two particular interlocutors, Joyce an RC Devel opment Facilitator, and Anna Maria, a Pentecostal Programme Co-ordinator, encapsulated the views and approaches of their colleagues with such clarity that I quote them at some length in the following discussion. Anna Maria, who had a university degree and a background as a church activist at a Pentecostal church, explained how prayer was a way to empowerment:

It helps people and takes them out of these beliefs that sometimes cause them not to have development [...] these pagan beliefs that cause people to continue being poor because of the thing they believe in. But I as a Christian, I know that Jesus can help. I have seen my faith help me. When I have problems, I pray to God and tell God that I'm not managing. Give me a plan to do this. Help me to get out of this problem of poverty. N ot that God drops down money. After prayers I hear that there is a plan coming. Maybeyou go to cultivate with this money, you harvest, and you increase the income. (162/ 2012, Anna Maria)

Many WV operatives (e.g. 161/ 2012, DA; 162/2012 PC; 209/ 2012 DA)

contrast Christians with those who hold 'pagan beliefs'; for a Christian, prayer is a form of agency and may result in empowerment by God in the form of an action plan. A pparently in analogy to WV paradigms of service delivery and empowerment, Anna Maria suggested that God does not deliver money but, rather, empowers with plans-a crucial aspect of agency-which are then translated through the medium of human agency into incomegenerating action, a narrative illustrating the intertwinement of secular development language and biblical ideas in WV discourse. Anna Maria further described WV's capacity-building seminars by using the parable of 
the talents and the importance of work for expanding capabilities:

When we do capacity building, we tell them that the Bible says, "The one who is unwilling to work shall not eat." So, the people have to agree to work; this is the first thing, to mobilise (kuhamazisha) people to work. There are al so various examples that Jesus gave, for instance the example of the talents. [...] When we teach the people things like that, we mean that our friends, the wazungu (white people) whom we depend on, give us things. It is not as if only they were blessed. They worked with the things that they were given. [...] Through these words of God and by giving various examples we teach people to value themselves and to see that they have the ability to work. [...] They start thinking that even [the wazungu] started like this and they arrived where they are now. So, we use the word of God. (162/2012, Anna Maria)

This well-known biblical parable ends with the servant who buried his single talent being cast into eternal damnation and, by deploying it, Anna Maria presented a Weberian understanding of a gift as divinely granted power or talent that needs to be put into productive labor (Weber [1930] 2004, 108). She also spoke about white people who are here seen as providing tal ents, implicitly questioning whether the service delivery practised by WV Tanzania until recently can be interpreted as a form of burying talents rather than putting them to work in empowering the people. The beneficiaries' spiritual deficiency, in addition to their material underdevel opment, is thereby highlighted in order to justify the relevance of spiritual ideas like agency and empowerment and ultimately to demand conversion as the avenue to development.

The social dimension of expanding capabilities and the outcome of activities in various incomegenerating groups are also presented in terms of Scripture. Christian transformation means, in this context, that a person will 
act independently rather than relying on other people or organisations such as WV, yet al so be positively committed to co-operation in collective community activities:

Jesus said, "Be united likel and my father were united." Therefore, in words such as these we have the Christian faith that makes us bring the people together. [...] We mobilise people to join groups so that they can be helped. For instance, last year and again this year we brought cows to the project. [...] This motivates people to join the groups because there is benefit in the group. [...] We teach the group members about the spirit of giving; this is the Christian faith. (162/ 2012, Anna Maria)

Here, the ambiguous opposites of independence and relatedness as well as independence and dependence resonate with the more general born-again Christian ideas of independent decision-making involved in becoming saved. Independence and relatedness are associated with a Christian attitude of communal co-operation and reciprocity in the spirit of the M aussian gift, which constructs social order and connects persons through the exchange of things (for another kind of Protestant gift-giving, see e.g. Coleman 2004). Consequently, dependency is associated with adhering to traditional behaviour rather than Christian values. According to many WV operatives (e.g. 160/ 2012 DA; 161/2012 DA; 173/2012 DA), faith-as a force in its own right and through the work ethic it inspires-is a personal empowering quality that is integral to achieving the good life:

First there is faith. There is faith that can bring the good life and there is faith that can make the person continue to have a poor life. [...] In [the book of] John, there is the verse where it is said that I want you to be successful in everything the way your soul allows. So, I believe that my Christian faith allows me to succeed [...] and I do not mean to be rich. If I guard this Christian faith well, it also urges me to work. 
If I work, I will be ableto get a bigger incomethan the one I havenow. (174/ 2012, Anna Maria)

In the spirit of the 'this is that' hermeneutic, the biblical 'I want you...' is brought into this world through the anal ogy 'I believe I...'. Thus biblical analogies set the development scene and appoint the primary protagoniststhe white sponsors of WV International, the staff, and the work of WV Tanzania, and, finally, the beneficiaries-producing an understanding of faith, prayer, and hard work as general conditions for development because 'everything that we have belongs to God'. Christian development is about progress at once spiritual and material, although it appears that, in the minds of WV staff members, work and Christian sociality are the most important elements.

\section{A gency, empowerment, and freedom}

During our conversations, WV staff also discussed secular development concepts, placing more emphasis, however, on personal agency and empowerment than on 'opportunity'. The other key informant, Joyce, had a diploma in community development and previous employment with another international faith-based organisation as well as considerable experience and a nuanced understanding of development issues in the communities. I asked her about empowering and constraining factors in terms of maisha bora. Her response emphasised the importance of self-awareness as an aspect of agency:

A person recognizes himself/ herself (kujitambua) [...] I mean that the person knows who he is, he knows his responsibilities, he plans the 
activities in the family; he has plans and visions. Even if this person does not haveanything today, wecan say that one day hewill succeed because he has plans and he knows who he is. (203/ 2012, Joyce)

The concept of kujitambua refers to a mature person reaching self-awareness and thereby becoming capable of realising his or her potential, which resonates with the idea of eudaemonic well-being, a state which captures people's perceptions of meaning and purpose in their lives and reflects the A ristotelian notion of life purpose (Mackie and Stone 2013, 19). Eudaemonic well-being is about living well in terms of realising one's human potential, which implies having the means and freedom to fulfil one's true life purpose (Graham and Nikolova 2015, 164). However, in the kinds of views described above and as is often the case in African cultures, self-recognition is by no means individualistic but, rather, socially embedded, relational, and invested with community, family, and kinship obligations. Joyce (also 175/ 2012 DA; 163/ 2012 DF) then discussed individual qualities that allow people to perceive opportunities that can facilitate well-being:

The [individual] ability of the person: he has good health and is not handicapped. [...] He has a mature mind (akili timamu) [...] and if he is empowered (kuwezeshwa), he can match the facts of his nature. (203/2012, Joyce)

A part from relating agency to such individual qualities as a state of mind (intelligence), body (health), and personality—and plans, objectives, and purposeful action-Joyce also suggested that it is more fruitful to work with people who have faith, an understanding shared by others (160/ 2012 DA; 209/ 2012 DA): 
We pray to God to help us because, if the community gets transformed, I will also be transformed and will have a different kind of life and not be backward any more. [...] Spiritual transformation is first, people should know God and [...] then there is the social transformation, education. [...] Transformation means changing people in such a way that they are more self-reliant (kujitegemea) and not asking for things [...] and weteach them to start groups. Therefore God comes first [...] when they first know God, then development follows. (161/ 2012, DA)

In the spirit of the WV theory of transformative development, this interviewee voiced the generally held WV view that a person with faith has the ability to learn new things and be transformed through that learning; the social relations of such a person are characterised by trust and mutual assistance, and such a person is more open to WV-style empowerment:

Really, for a person to succeed in all the things he wants to do, he has to have faith. If a person has faith $\{. .$.$\} he believes that everything he$ does will bear fruit. Somebody who has faith will decrease those things that can lead him astray (kupotosha) [...] takehim to somewhere zero. Faith helps to bring about changes. [...] So, I believe that faith can help a lot in bringing development and rapid changes. (203/2012, Joyce).

While biblical ideas are used to stage the principal protagonists of the development drama, here, an explicit comparison and evaluation are made regarding people who have and do not have faith; not only is there an indication of deficiency in the case of the latter, but also present is the implication that worldly development can only be achieved through WV's empowerment where there is faith. According to these views, even if 'people without religion' have plans-in a secular sense, faith is the ultimate way to the expand one's capabilities. Having faith is al so thought to contribute to 
social relations and the potential for expanding one's capabilities, both tangibly-in terms of not wasting money-and intangibly, through the acquisition of knowledge and information from faith institutions.

On the other hand, traditional beliefs and a past that binds are associated with lack of freedom and seen to lead to a lack of relational wellbeing and the intergenerational continuation of poverty (e.g. 166/2012 DA; 173/ 2012 DA; 174/ 2012 PC). As Joyce explained:

A nother challenge is the misleading beliefs (imani potovu) [...] thinking that [...] "Sincethetime of the ancestors there has never been anybody rich in our clan. Therefore we are the way we are" [... They say:] "You know we are like this. I tell you, my grandfather was like this, where would I get weal th?" He does not have the faith that he can change. (203/2012, Joyce)

Meanwhile, 'pagan' and 'traditional' beliefs in this area (Mesaki 1994;

Mihangwa 2000) are also considered disruptive to social relations and wellbeing because of their association with witchcraft:

You see that the useless beliefs (imani potovu) contribute a lot. With witchcraft, when a child is ill with ordinary malaria, [the father] goes to a mganga [witch doctor] [...] [because] he believes that any person who is ill is bewitched by somebody. (166/2012, DA)

Thus, the Christian foundations of sociality and expanded capabilities are seen as bringing peace and neighbourly love, whereas 'pagan' beliefs may even cause the murders of those accused of witchcraft (M esaki 1994, 48, 52). Finally, James Ferguson $(2013,225)$ has noted that (resonating with WV views) Sen (1999) defines development as an increase in individual freedom, rendering dependence the very opposite of developmental progress. 
However, as Ferguson notes, one might arguein regard to much of Africa that "without networks of dependence, you were nobody except perhaps a witch", but with networks you could be a person of consequence $(2013,227)$.

\section{Conclusion}

This article has discussed the fusing of secular and spiritual ideas in faithbased development via the development evaluations of Tanzanian project staff at World Vision, an international faith-based organisation that is remarkably little studied at grassroots levels, given its outreach and magnitude. A nalysis has addressed, firstly, how WV's shared faith base functions as the source of social meanings and values in assessing agency, empowerment, and freedom-important dimensions of contemporary development-and, secondly, how WV operatives compare and value Christian and non-Christian development potential while investing secular concepts with religious meaning.

A frequently asked policy-related question is whether faith-based development has distinctive added val ue compared to secular development, yet there is limited information currently available about the precise dynamics of faith in development projects. In order to understand its role better, we need to examine how development practitioners actually communicate and interact with beneficiaries on the ground, investigating how faith impinges on practitioners' ideas of development and affects decisions and actions about the way development is conducted and 
communicated. The goal of WV's theory of transformational development is to change people and relationships on the understanding that spiritual transformation brings about transformations in other areas of human life as well. It is approached by way of what Yong (2010) has defined as a 'this is that' hermeneutic, whereby biblical anal ogies and parables are used to create a favourable representation of development actors and a spiritual and material deficiency among beneficiaries, thus generating motivation and moral justification for WV's work and, ultimately, spiritual transformation. Biblical analogies are established as agents of development and forms of agency, empowerment, and freedom and these secular concepts are imbued with religious meaning. Biblical parables such as that of the talents establish the actors of the development drama and proclaim human labour as an essential form of agency. For a Christian, however, prayer is perhaps the most vital form, providing the potential of Godly empowerment. Prayer may result, in Rowland's (1997) terms, in means, plans or the power to generate new capabilities through God-given plans and new ideas. Collective action or power with is portrayed by way of a biblical analogy of relatedness and independence as a form of Christian development practice, unlike 'traditional' life, which is characterised by dependency. Furthermore, Christian faith is portrayed as providing the faithful with a third form of empowerment, power from within, by strengthening such dimensions of agency as self-awareness, inner potential, and Christian ethics. Ultimately, empowerment is constituted through evaluations that the Christian faith lets 
a person 'be successful in everything to the extent that his/ her soul allows', be free and not bound by harmful traditional practices leading to 'somewhere zero'. Traditional culture and the 'pagan' worldview are portrayed as the antithesis of the Christian faith due to their influence on agency, empowerment, and freedom. Although conversion and salvation are rarely directly addressed, the gospel is perceived to be spread through a holistic approach to word and deed and the Christian witness of lifestyle evangelism.

\section{Acknowledgments}

I would like to thank the A cademy of Finland for supporting this study as part of my research on "Religion and Globalization: Evangelical Christianity and Development in A frica" (grant number 251277) and the Tanzania Commission for Science and Technology for providing me with research clearance. I am grateful to A nceth Jettah, Vivian Baitu, Sofia Joseph, and Deusdediti M panduji for their research assistance. Earlier versions of this article were commented on by Maia Green, Sirkku Hellsten (†), Anja Nygren, Barry Gills, Sarah White, Séverine Deneulin, and the participants of the Development Studies Association Conference in Bath in September 2015. I am particularly grateful to World Vision Tanzania and its staff for their generous and gracious collaboration during the project. I am indebted to Dr MarieLouise Karttunen for patiently editing the language of this article.

\section{D isclosure Statement}


No potential conflict of interest is reported by the author.

\section{N otes on contributor}

Päivi $\mathrm{H}$ asu is an anthropologist educated at the University of Helsinki and A djunct Professor in Ethnology at the University of Jyväskylä, Jyväskylä, Finland, where she currently holds the position of a university teacher. Her past research and research interests have been in the field of anthropology of Christianity and involved an historical study of the ritual practices of the Chagga of Kilimanjaro, research on the charismatic movement within the Lutheran church in Tanzania, and studies on the new Pentecostal-charismatic churches in Dar es Salaam. M ost recently, she has researched faith-based organisations and their development projects in Tanzania.

CORRESPONDENCE: Department of Social Sciences and Philosophy, University of Jyväskylä, PO Box 35, FI-40014 University of Jyväskylä, Finland.

\section{References}

Bebbington, David. 1989. Evangelicalism in M odern Britain: A H istory from the 1730s to the 1980s. London: Unwin Hyman.

Bornstein, Erica. 2005. The Spirit of D evelopment: Protestant N G O s, M orality and E conomics in Zimbabwe. Stanford, CA: Stanford University Press.

Calestani, Melania. 2009. “An Anthropology of 'The Good Life' in the Bolivian Plateau." Social Indicators Research 90 (1): 141-153.

Calestani, Melania. 2013. An A nthropological Journey into W ell-being: Insights from Bolivia. Dordrecht: Springer. 
Clarke, Gerard, and Michael Jennings, eds. 2008. D evelopment, Civil Society and Faith-based O rganizations: Bridging the Sacred and the Secular. Basingstoke: Palgrave Macmillan.

Clarke, Matthew, ed. 2013. H andbook of Research on D evelopment and R eligion. Cheltenham: Edward Elgar.

Coleman, Simon. 2004. “The Charismatic Gift." Journal of the R oyal A nthropological Institute 10 (2): 421-442.

Deacon, Gregory, and Emma Tomalin. 2015. “A History of Faith-based Aid and Development." In The R outledge H andbook of R eligions and Global D evel opment, edited by Emma Tomalin, 68-79. London: Routledge.

Deneulin, Séverine, and Masooda Bano. 2009. Religion in D evelopment: Rewriting the Secular Script. London: Zed.

Deneulin, Séverine, and Allister McGregor. 2010. “The Capability A pproach and the Politics of a Social Conception of Well-being." European Journal of Social Theory 13 (4): 501-519.

Deneulin, Séverine, and Carole Rakodi. 2011. “Revisiting Religion: Development Studies Thirty Years On." W orld D evel opment 39 (1): 45-54. De Wet, Hannah Lindiwe. 2013. “Transformational Development: World Vision South Africa's Response to Poverty." In International D evelopment Policy: Religion and D evelopment, edited by Gilles Carbonnier, 95-111. London: Palgrave.

Ferguson, James. 2013. “Dedarations of Dependence: Labour, Personhood, and Welfare in Southern Africa." Journal of the R oyal A nthropological 
Institute 19 (2): 223-242.

Fischer, Edward. 2014. The G ood Life: A spiration, Dignity, and the A nthropology of W ell being. Stanford, CA: Stanford University Press.

Graham, Carol, and Milena Nikolova. 2015. “Bentham or A ristotle in the Development Process? An Empirical Investigation of Capabilities and Subjective Well-Being." W orld D evelopment 68 (A pril): 163-179.

Hasu, Päivi. 2012. “Prosperity Gospels and Enchanted World Views: Two Responses to Socio-economic Transformations in Tanzanian Pentecostalcharismatic Christianity." In Pentecostalism and D evelopment: Churches, N GO s and Social Change in A frica, edited by Dena Freeman, 67-86.

Basingstoke: Palgrave Macmillan.

Hasu, Päivi. 2016. “Pentecostal-charismatic Christianity and Development: Views from Africa." In For Better and for W orse: The R ole of Religion in D evelopment Cooperation, edited by Robert Odén, 91-102. Stockholm: Swedish Mission Council.

Haynes, Jeffrey. 2007. Religion and D evelopment: Conflict or Cooperation?

Basingstoke: Palgrave Macmillan.

Haynes, N aomi. 2016. “Theology on the Ground: The Politics of the Expansive

Present." Paper presented at the conference on “African Lived

Christianity: Faith, Ritual and Power", Lund University, Lund, Sweden, 16-18 March.

Ibrahim, Solava, and Sabine Alkire. 2007. "Agency and Empowerment: A Proposal for Internationally Comparable Indicators." O xford D evelopment 
Studies 35 (4): $379-403$.

Jefferess, David. 2002. “For Sale Peace of Mind: (Neo-)Colonial Discourse and the Commodification of Third World Poverty in World Vision's

'Telethons'." Critical A rts: A South-N orth Journal of Cultural \& M edia Studies $16(1): 1-21$.

Jimenez, Alberto, ed. 2008. Culture and W ell-being: A nthropological A pproaches to Freedom and Political Ethics. London: Pluto.

Kelsall, Tim, and Claire Mercer. 2003. “Empowering People? World Vision \& 'Transformatory Development' in Tanzania." Review of A frican Political Economy $<$ Q $>$ Vol 30 (96): 293-304.

King, David P. 2011. “World Vision: Religious Identity in the Discourse and Practice of Global Relief and Development." The Review of Faith and International A ffairs 9 (3): 21-28.

Lambek, Michael. 2008. “Measuring_or Practising-Well-being." In Culture and W ell-being: A nthropological A pproaches to Freedom and Political Ethics, edited by Alberto Jimenez, 115-133. London Pluto Press.

Lloyd, Geoffrey E. R. 1966. Polarity and A nalogy: Two Types of A rgumentation in Early Greek Thought. Cambridge: Cambridge University Press.

Mackie, Christopher, and Arthur Stone. 2013. Subjective W ell-being: M easuring $\mathrm{H}$ appiness, Suffering, and O ther D imensions of Experience. Washington, DC: National Academies Press.

Magesa, Laurenti. 1998. A frican Religion: The M oral Traditions of A bundant Life. Nairobi, Kenya: Paulines Publications Africa. 
Marshall, Ruth. 2009. Political Spiritualties: The Pentecostal Revolution in Nigeria.

Chicago, IL: Chicago University Press.

Mathews, Gordon, and Carolina Izquierdo, eds. 2009. Pursuits of H appiness:

W ell-being in A nthropological Perspective. NewYork: Berghahn.

Mesaki, Simeon. 1994. "Witch-killing in Sukumaland." In W itchcraft in

Contemporary Tanzania, edited by Ray Abrahams, 47-60. Cambridge:

University of Cambridge A frican Studies Centre.

Mihangwa, Joseph. 2000. V iolence against the A ged: The Case of Killings on

W itchcraft Beliefs in Shinyanga Region. Dar es Salaam: Tanzania M edia

Women's Association.

Myers, Bryant. (1999) 2011. W alking with the Poor: Principles and Practices of

Transformational D evelopment. Maryknoll, NY: Orbis.

Olsson, Hans. 2016. “Jesus for Zanzibar: Narratives of Pentecostal Belonging, Islam and Nation." PhD diss., Lund University.

Plant, Stephen, and Danie H. Weiss. 2015. “Theology and Development:

Christian and Jewish A pproaches." In The R outledge $\mathrm{H}$ andbook of Religions and Global D evelopment, edited by EmmaTomalin, 53-67. London:

Routledge.

Robbins, Joel. 2013. “Beyond the Suffering Subject: Toward an A nthropology of the Good." Journal of the Royal A nthropol ogical Institute 19 (3): 447-462.

Rowlands, Jo. 1997. Q uestioning Empowerment: W orking with W omen in H onduras. Oxford: Oxfam.

Sen, A martya. 1979. "Equality of What?" In Tanner Lectures on Human Values, 
Vol 1, edited by Sterling M. McMurrin, 195-220. Salt LakeCity, UT:

University of Utah Press.

Sen, A martya. 1999. D evelopment as Freedom. New York: Knopf.

Stewart, Frances. 2013. Capabilities and H uman D evelopment: Beyond the Individual: The Critical Role of Social Institutions and Social Competences.

United Nations Development Programme. Occasional paper 2013/ 03.

http:/ / hdr.undp.org/ sites/ default/ files/ hdro_1303_stewart.pdf, accessed September 22, 2018.

Strenski, Ivan. 2008. D umont on Religion: D ifference, Comparison, Transgression. London: Equinox.

Ter Haar, Gerrie, ed. 2011. Religion and D evelopment: W ays of Transforming the W orld. London: Hurst.

Tomalin, Emma. 2013. Religions and D evelopment. London: Routledge.

Tomalin, Emma, ed. 2015. The R outledge H andbook of Religions and Global

D evelopment. London: Routledge.

Tyndale, Wendy. 2006. V isions of D evelopment: Faith-based Initiatives.

Aldershot: Ashgate.

United Nations Development Programme, UNDP. 1990. H uman D evelopment Report 1990. New York: Uxford University Press.

http:/ / hdr.undp.org/ sites/ default/ files/ reports/ 219/ hdr_1990_en_com plete_nostats.pdf, accessed September 22, 2018.

Weber, Max. (1930) 2004. The Protestant Ethic and the Spirit of Capitalism. London: Routledge. 
Whaites, Alan. 1999. "Pursuing Partnership: World Vision and the Ideology of

Development-a Case Study." D evelopment in Practice 9 (4): 410-423.

World Vision Tanzania. 2012. W orld V ision Tanzania N ational O ffice Strategy FY

13-15.

http:/ / www.wvi.ngo/ sites/ default/ files/ WVT\%20Strategy\%20FY\%2013

\%20-\%2015\%20Final\%20Crt20\%20040313.pdf, accessed September 21,

2018.

World Vision. 2013. W orld Vision's Theory of Change. Summary. January 2013.

https:/ / www.wvi.org/ sites/ default/ files/ WV\%20Theory\%20of\%20Cha

nge.Summary_0.pdf, accessed September 21, 2018.

Yong, A mos. 2010. In the D ays of Caesar: Pentecostalism and Political Theology.

Grand Rapids, MI: W. B. Eerdmans.

\section{N otes}

${ }^{1}$ This article is not the place to analyse the various definitions of religion and faith. Religion is used here to refer to a particular system of faith and worship, whereas faith is used to refer to an internalised, all-embracing spiritual experience and trust in something that cannot be proven. Hence, a person with faith would not perceive a dichotomy between the sacred and the secular.

2 These observations have enabled religion to be granted more space within studies of development, a trend which is evident in the rapidly growing number of important publications (Bornstein 2005; Clarke 2013; Deneulin and Bano 2009; H aynes 2007; ter Haar 2011; Hasu 2012, 2016; Tyndale 2006; Clarkeand Jennings 2008; Tomalin 2013, 2015).

${ }^{3}$ Louis Dumont discusses the principles of hierarchy and the principle of encompassing of the contrary in his classic work Homo Hierarchicus (Chicago Uiversity Press 1980). The idea of hierarchy in his sense is that a hierarchy is a way of looking at the world and imagining social reality rather than a thing in itself. It is a system of difference or asymmetry, which arises whenever one makes a judgement of value. Hierarchy is a system where differences are encompassed and subordinated to the whole; it is a kind of holism (Strenski 2008, 25-26).

${ }^{4}$ The identification of the informant indicates first the chronological number of the interview (208), the year of the interview (2012), the denomination of the informant (AIC for A frican Inland Church) and the gender of the informant. The acronyms for the denominations are mentioned in the description of the fieldwork. 